\title{
EFFECTIVENESS OF NUTRITION EDUCATION IN IMPROVING KNOWLEDGE AND CHILD NUTRITION STATUS AMONG MOTHERS WHO HAVE MALNOURISHED CHILDREN IN PEKANBARU, RIAU
}

\author{
Mitra, Herlina Susmaneli, Winda Septiani \\ School of Health Sciences Hang Tuah, Pekanbaru
}

\begin{abstract}
Background: Good nutrition is important for children. Children are at a time in their life when they are constantly growing and learning new knowledge. In order for children to grow properly, they must eat a well-balanced diet. This study aimed to determine the effectiveness of nutrition education in improving knowledge and child nutrition status among mothers who had malnourished children in Pekanbaru, Riau.

Subjects and Method: This was aquasi experiment study before and after with control design conducted in Pekanbaru, Riau. A total of 3omothers who had malnourished infants were allocated in two groups, consisting of 15 mothers with nutrition education in the intervention group, and 15 mothers without nutrition education in the control group. The dependent variable was maternal knowledge in exclusive breastfeeding (EBF), nutritional menu, nutrition parenting, and child nutrition status. The independent variable was nutrition education. Child nutritional status was measured by weight for age $\mathrm{Z}$ scores. The other data were collected by questionnaire. Changes in knowledge scores as well as $\mathrm{Z}$ scores beforeandafter nutrition education between the intervention and the control groups were compared by t test.

Results:Increase of knowledge in EBF before and after in the intervention group was 2.34 unit higher than in the control group ( $<<0.001)$. Increase of knowledge in nutrition menu before and after in the intervention group was 1.93 unit higher than in the control group ( $\mathrm{p}<0.001)$. Increase of knowledge in nutrition parenting before and after in the intervention group was 1.73 unit higher than in the control group $(\mathrm{p}<0.001)$. Increase in $\mathrm{Z}$ score before and after in the intervention group (o.6) was higher than in the control group (0.24) with $\mathrm{p}<0.001$.

Conclusion: Nutrition education is effective to improve maternal knowledge in $\mathrm{EBF}$, nutrition menu, nutrition parenting, and to increase nutritional status of infants.
\end{abstract}

Keywords: malnourished, nutrition, education, knowledge, children, mother.

\section{Correspondence:}

Mitra. Masters Program in Public Health, School of Health Sciences Hang Tuah, Pekanbaru, Jl. Mustafa Sari No. 5, Tangkerang Selatan Pekanbaru, Riau.

Email: mitra@htp.ac.id. Mobile: 08126731772 